\title{
International Criminal Law in Swedish Courts: The Principle of Legality in the Arklöv Case
}

\author{
Mark Klamberg \\ PhD Student, Department of Law, Stockholm University, Sweden
}

\begin{abstract}
On 18 December 2006, the Stockholm district court convicted Jackie Arklöv for a crime against international law. It was the first, and until the present date, the only time, liability for a crime against international law has been tried before a Swedish court. This article presents the law applied by the Court, draws attention to the principles of legality, ne bis in idem, and discusses whether a national court in a dualistic legal system can impose criminal responsibility with reference to customary international law.
\end{abstract}

\section{Keywords}

principle of legality; Jackie Arklöv; crime against international law; war crime; unlawful confinement

\section{Introduction}

Legal proceedings concerning international crimes may take place before an international court or tribunal, a domestic court or a hybrid of these. The idea behind the establishment of the International Criminal Tribunal for the former Yugoslavia (ICTY) and the International Criminal Tribunal for Rwanda (ICTR) was not to render national prosecutions of international crimes impossible. The complementarity principle underlying the jurisdiction of the International Criminal Court (ICC) has underscored the key role of national courts in evolving an effective system of international criminal justice. ${ }^{1}$

When confronting prosecutions of international crimes, national courts will be required to apply a combination of national and international law. Furthermore, in the dualistic legal system of Sweden the courts have to determine whether they can impose criminal responsibility on the basis of a reference in the Swedish penal code to customary international law. Would an affirmative answer to this question be in accordance with the principle of legality?

\footnotetext{
1) The Rome Statute of the International Criminal Court of 17 July 1998, UN Doc. A/Conf.183/9, (hereinafter Rome Statute).
} 
The present study will discuss the abovementioned issues as resolved in the Arköv case. Jackie Arklöv committed atrocities during the armed conflict in the former Yugoslav republics and was convicted for crime against international law by the district court of Stockholm. ${ }^{2}$ It was the first and, until the present date, the only time liability for an international crime has been tried before a Swedish court. As no appeal was lodged the Court's judgment has become final.

\section{Applicable Law}

\subsection{National Jurisdiction and Competence to Adjudicate}

Under Brottsbalken (the Swedish Penal Code, hereinafter BrB) Chapter 2, Section 2, Paragraph 1, a Swedish court may exercise jurisdiction over crimes committed outside Sweden according to Swedish law where the crime has been committed by a Swedish citizen or an alien domiciled in Sweden (the active personality principle). ${ }^{3}$ In other countries, it is normal to uphold this principle with regard to war crimes. ${ }^{4}$ A requirement in this Section is that act is both subject to criminal responsibility under the law of the place where it was committed and under Swedish law, in other words there is a double criminality rule. In addition, according to $\mathrm{BrB}$ Chapter 2, Section 3, Paragraph 6, a Swedish court may adjudicate crimes against international law, regardless of the nationality of the perpetrator and the place where the act was committed. The provision is based on the universality principle. There is no requirement on double criminality in the latter case. However, prosecution for a crime committed outside of Sweden requires the authorization of the Government or an authority empowered by the Government. ${ }^{5}$

\subsection{Substantial Law}

Traditionally the Swedish legal system has been described as dualistic where international law is implemented through transformation. In recent years there has been a trend towards direct applicability of international law, for example through the incorporation of the European Convention on Human Rights and the EU membership. ${ }^{6}$ The implementation of international criminal law is a third

2) Prosecutor v. Jackie Arklöv, Stockholm District Court, Case no. B 4084-04, Judgment of 18 December 2006.

3) Brottsbalken (1962), translated to English in Ds 1999:36, 1999.

4) Antonio Cassese, International Criminal Law, (Oxford: Oxford University Press, 2003) at 281.

5) BrB Chapter 2, Section 5, Paragraph 2.

6) Iain Cameron, 'Swedish Investigations for Gross Human Rights Violations, Actual and Possible' in Flores juris et legum: festskrift till Nils Jareborg, Iustus, Uppsala, 2002, at 148; Ove Bring and 
example of the direct applicability of international law. ${ }^{7}$ BrB Chapter 22, Section 6 defines international crimes under Swedish law and it provides that:

A person guilty of a serious violation of a treaty or agreement with a foreign power or an infraction of a generally recognised principle or tenet relating to international humanitarian law concerning armed conflicts shall be sentenced for crime against international Law to imprisonment for at most four years.

$\ldots$

If the crime is gross, imprisonment for at most ten years, or for life shall be imposed. In assessing whether the crime is gross, special consideration shall be given to whether it comprised a large number of individual acts or whether a large number of persons were killed or injured, or whether the crime occasioned extensive loss of property.

This means that international treaties as well as customary international law concerning international humanitarian law are applicable in the determination whether a crime against international law has been committed. ${ }^{8}$ The incorporation of parts of international criminal law by reference (renvoi) is not unique for Sweden. ${ }^{\text {? }}$

The predecessor to the current provision on crime against international law was introduced in connection with the reform of the old penal code (strafflagen) $1948 .{ }^{10}$ It was amended in 1954 and the substantial content was kept intact in BrB Chapter 22, Section 11 when the penal code of $1962(\mathrm{BrB})$ was introduced. Through legislation 1986 the provision was moved to its current place in $\mathrm{BrB}$ and at the same time it was amended to its current wording. Among other things, the last amendment restricted the scope of the provision to the most serious violations of international law. ${ }^{11}$ These serious violations shall be understood to include:

1. use of any weapon prohibited by international law,

2. misuse of the insignia of the United Nations or of insignia referred to in the Act on the Protection of Certain International Medical Insignia (Law

Said Mahmoudi, Sverige och folkrätten, Norstedts Juridik AB, Stockholm, 2001, at 42. Håkan Friman, 'Political and Legal Considerations in Sweden Relating to the Rome Statute for the International Criminal Court' in States' Responses to Issues Arising from the ICC Statute, Constitutional, Sovereignty, Judicial Cooperation and Criminal Law, Editor: Roy S. Lee, Transnational Publishers, Ardsley, 2005, at 123.

7) These examples can be explained both under monist and dualist theories. Rules of reference to international law may be evidence of a monist attitude when they are declarative, but of a dualist attitude when they are constitutive. It is submitted that the latter case applies to the Swedish judicial system and the mentioned examples. See Ward N. Ferdinandusse, Direct Application of International Criminal Law in National Courts, $\mathrm{T} \bullet \mathrm{M} \bullet \mathrm{C}$ Asser Press, The Hague, 2006, at 130.

8) Nils Jareborg, Brotten tredje häftet, Sthlm 1986, at 223.

9) See Ferdinandusse, supra note 7, at 2. Ferdinandusse defines direct application of international law 'when it has force of law in the national legal order' (at 8).

10) NJA II 1949 at 185-190.

11) SOU 2002:98, Internationella brott och svensk jurisdiktion, Statens Offentliga Utredning (Swedish Government Official Report), part 2 at 243-4. 
1953:771), parliamentary flags or other internationally recognised insignia, or the killing or injuring of an opponent by means of some other form of treacherous behaviour,

3. attacks on civilians or on persons who are injured or disabled,

4. initiating an indiscriminate attack knowing that such attack will cause exceptionally heavy losses or damage to civilians or to civilian property,

5. initiating an attack against establishments or installations which enjoy special protection under international law,

6. occasioning severe suffering to persons enjoying special protection under international law; coercing prisoners of war or civilians to serve in the armed forces of their enemy or depriving civilians of their liberty in contravention of international law; and

7. arbitrarily and extensively damaging or appropriating property which enjoys special protection under international law in cases other than those described in points 1-6 above. ${ }^{12}$

The provision indicates which acts constitute serious violations of international law, but it is not an exhaustive list but rather an exemplification. The mix of a general rule of reference and a list of examples may be found in other countries. ${ }^{13}$ It is also notable that $\mathrm{BrB}$ Chapter 22, Section 6 makes no distinction between rules applicable in international and non-international armed conflicts.

In addition, genocide is criminalized under the Genocide Act (1964:169), which uses a definition that corresponds with the 1948 Convention on the Prevention and Punishment of the Crime of Genocide. ${ }^{14}$ Considering the fact that $\mathrm{BrB}$ Chapter 22, Section 6 only covers crimes against humanitarian law, it is noteworthy that Sweden does not have any specific law covering crimes against humanity. According to the Swedish Government such offences are already criminalized under Swedish law, for example there is no explicit provision on torture as this is covered by the provision on assault. ${ }^{15}$

Against the background that Sweden was intending to ratify the Rome Statute of the International Criminal Court and following a Government resolution on 12 October 2000, the Swedish Commission on International Criminal Law was set up to review Swedish legislation on criminal responsibility for international crimes and jurisdiction over such crimes. The assignment was extended to include a review of Swedish legislation on criminal jurisdiction in general. In November 2002 the Commission presented its report International Crimes and Swedish Jurisdiction (SOU 2002:98).

12) BrB Chapter 22, Section 6.

13) For example the Finnish Penal Code, Chapter 11, Section 5 (amended 2008).

14) Lag (1964:169) om straff för folkmord.

15) BrB Chapter 3, Section 5 and see SOU 2002:98, supra note 11, part 1 at 173. 
The proposal of the Commission would, among other things, entail that the Genocide Act would be repealed and the provision in BrB Chapter 22, Section 6 would be replaced by a new Swedish Act on International Crimes. The Act will make it possible to hold individuals responsible for genocide, crimes against humanity and war crimes. The provisions of the Rome Statute have been the primary model of the proposal. It is submitted that the Rome Statute is a compromise and to some extent an expression of the least common denominator at the Rome conference. ${ }^{16}$ Thus, the scope of the Rome Statute may be more limited in some parts and more expansive in others in comparison with customary international law. The fact that the proposal from Swedish Commission on International Criminal Law is an exhaustive list of criminalized acts may have the consequence that the future Act will have a different scope than the present open ended provision in $\mathrm{BrB}$ Chapter 22, Section 6. It is uncertain when Ministry of Justice will present a legislative proposal to the Council on Legislation (lagrådet). ${ }^{17}$

\subsection{The Geneva Conventions of 1949 and the Additional Protocols of 1977}

A contentious issue in the Arklöv case was whether to apply rules pertaining to international or a non-international armed conflict, the previous providing a more extensive protection. The primary scope of the four Geneva Conventions of 1949 (Geneva Conventions) and the First Additional Protocol of 1977 (AP I) is international armed conflicts. In a non-international armed conflict Common Article 3 of the Geneva Conventions and the Second Additional Protocol of 1977 (AP II) are applicable, containing minimum standards.

With this background on the legal framework the following minimum protection is relevant in non-international armed conflicts. According to Common Article 3 of the Geneva Conventions, prisoners of war:

shall in all circumstances be treated humanely, without any adverse distinction founded on race, colour, religion or faith, sex, birth or wealth, or any other similar criteria. To this end, he following acts are and shall remain prohibited at any time and in any place[...]: violence to life and person, in particular murder of all kinds, mutilation, cruel treatment and torture.

Furthermore, taking of hostages is prohibited, the wounded and sick shall be collected and cared for. By the use of the words 'in all circumstances', Article 27

16) Compare with Herman von Hebel and Darryl Robinsson who emphasise the fact that recent developments from the ad hoc tribunals were taken into account during the drafting of the Rome Statute. Herman von Hebel and Darryl Robinsson, 'Crimes within the Jurisdiction of the Court', Roy S. Lee. (Ed.), The International Criminal Court: the Making of the Rome statute: Issues, Negotiations and Results, Kluwer Law International, The Hague, 1999, at 122.

17) The Council on Legislation is a body mainly composed of Supreme Court and Supreme Administrative Court Judges which carries out judicial preview. 
of Geneva Convention IV appears to apply in international as well as noninternational conflicts:

protected persons are entitled, in all circumstances, to respect for their persons, their honour, their family rights, their religious convictions and practices, and their manners and customs. They shall at all times be humanely treated, and shall be protected especially against all acts of violence or threats thereof and against insults and public curiosity.

From Article 4 of AP II it may be concluded that:

[A]ll persons who do not take a direct part or who have ceased to take part in hostilities, whether or not their liberty has been restricted, are entitled to respect for their person, honour and convictions and religious practices. They shall in all circumstances be treated humanely, without any adverse distinction.

Some acts are prohibited at all times, such as corporal punishment; collective punishments; pillage; and threats to commit any or the foregoing acts. According to Article 5 of AP II persons deprived of their liberty shall be treated if they are wounded or sick. Article 13 of AP II requires protection for the civilian population.

By the use of the notion 'serious violations' BrB Chapter 22, Section 6 connects to Article 50 of Geneva Convention I, Article 51 of Geneva Convention II, Article 130 of Geneva Convention III, Article 147 of Geneva Convention IV, and Article 85 of AP I which specifies which acts are considered to be 'grave breaches', including murder, torture, inhuman treatment, unlawful deportation or transfer or unlawful confinement of a protected person.

In international armed conflicts there is a considerable amount of additional protective rules and principles, for example the principle of distinction (Article 48 and 51(2) of AP I) and the principle of proportionality (Article 51(5)(b) of AP I). Of particular relevance for the present case is Article 78 of Geneva Convention IV which provides that the occupying power may confine civilians for imperative reasons of security' and that 'it may, at the most, subject them to assigned residence or to internment' at the condition that the measures shall be made according to a legal procedure.

\subsection{The Prohibition of Double Jeopardy (Ne bis in idem)}

The Swedish Code of Judicial Procedure (RB) Chapter 30, Section 9 provides that ' $\mathrm{o}]$ nce the time for ordinary means of appeal has expired, the issue of the defendant's criminal liability for the act which was determined by the judgment may not be taken up again for adjudication.' This rule reflects the prohibition of double jeopardy, also known as the ne bis in idem principle. The Swedish Commission on International Criminal Law has analyzed whether the ne bis in 
idem principle, as it is formulated in $\mathrm{RB}$, applies to foreign judgments. ${ }^{18}$ In the view of the commission the rule in RB Chapter 30, Section 9 only applies to the legal effect of a Swedish judgment. The traditional approach in Sweden has been that adjudications in a state are not binding vis-à-vis a court in a state other than the first state. ${ }^{19}$ For criminal proceedings this would mean that foreign judgments in criminal cases would not shield a person from prosecution in Sweden for the same act. However, at the present time, the principle ne bis in idem applies to a large extent even to judgments from other states. In connection with the Swedish accession to the 1970 European Convention on the International Validity of Criminal Judgments (Criminal Judgment Convention) ${ }^{20}$ a provision was introduced in BrB Chapter 2, Section 5(a). According to the aforementioned provision a person may not be prosecuted for an act when 'the question of responsibility for [the] act has been determined by a judgement which has entered into legal force pronounced in a foreign state where the act was committed, or by a foreign state in which the [Criminal Judgment Convention] was in force.' This applies if the person has been acquitted, if he or she has been declared guilty of the crime without a sanction being imposed, if the sanction imposed has been enforced in its entirety or enforcement is in process, or if the sanction imposed has lapsed under the law of the foreign state. In the second paragraph of the provision there are certain exceptions.

Does BrB Chapter 2, Section 5(a) imply that all foreign judgments should be respected? The Commission's assessment is that for international crimes Sweden may be under a duty to prosecute regardless of the nationality of the perpetrator and the place where the act was committed. According to the Commission this would also mean that Sweden can not respect a judgment from a court in an other state where a case has been tried concerning international crimes on the basis that the act is subject to impunity in the country where the judgment was delivered.

Furthermore, '[i]f the question of responsibility for an act has been determined by a judgment pronounced by a foreign state and no impediment to legal proceedings exists by reason of what has been previously stated in this Section, the act may be prosecuted in [Sweden] only by order of the Government or a person authorised by the Government. ${ }^{.21}$

\footnotetext{
18) See SOU 2002:98, supra note 11, part 1, at 104-6.

19) Antonio Cassese also holds the view that it is controversial whether the prohibition of double jeopardy, applying to relations between states, is a customary rule of international law, see Cassese, supra note 4 , at 319.

20) European Convention on the International Validity of Criminal Judgments, Swedish International Agreements, SÖ 1973:55, The Hague, 1970, European Treaties, ETS No. 70.

21) BrB Chapter 2, Section 5(a), Paragraph 3; According to Section 1, Paragraph 3 of Government decree 1993:1467 the Government has authorised the Prosecutor-General to decide upon these cases.
} 


\subsection{The Principle of Legality}

The principle of legality, nullum crimen sine lege, is at the foundation of Swedish criminal law, with the essential goal of guaranteeing legal certainty. Requirements on specificity, non-retroactivity, foreseeability, and accessibility of the law are at the core of the principle of legality. ${ }^{22}$ The principle has a prominent position in Chapter 2 Section 10 of the Instrument of Government (regeringsformen), ${ }^{23}$ Section 5 of the law on the introduction of $\mathrm{BrB},{ }^{24} \mathrm{BrB}$ Chapter 1 Section 1 and the 1950 European Convention on Human Rights (ECHR) incorporated in Swedish law. ${ }^{25}$ The principle of legality is also codified in Article 15(1) of the 1966 International Covenant on Civil and Political Rights (ICCPR). A prohibition on extending criminal liability by analogy follows from the principle of legality. Nevertheless, Article 15(2) of the ICCPR stats that '[n] othing in this Article shall prejudice the trial and punishment of any person for any act or omission which, at the time when it was committed, was criminal according to the general principles of law recognized by the community of nations.' Article 7(2) of the ECHR contains a similar exception and some states have followed this example. ${ }^{26}$ State practice in this regard is divided. There is no such exception clause in the Instrument of Government. This implies that Swedish law follows a strict interpretation of the principle of legality. ${ }^{27}$ For the present case it is relevant to discuss whether custom constitutes law in the sense of nullum crimen sine lege. The present author will attempt to answer this question in his comments to the case.

\section{The Arklöv Case}

According to the indictment Jackie Arklöv was responsible for a serious violation of a treaty or agreement with a foreign power and an infraction of a generally recognized principle or tenet relating to international humanitarian law concerning armed conflicts by inflicting severe suffering to persons enjoying special protection under international law; coercing prisoners of war or civilians to serve in the

\footnotetext{
22) See Ferdinandusse, supra note 7, at 222-3 and 236.

23) The Swedish Constitution consists of four fundamental laws: the Instrument of Government, the Act of Succession, the Freedom of the Press Act, and the Fundamental Law on Freedom of Expression.

24) Lagen (1964:163) om införande av BrB.

25) The relevant case law is very limited, NJA 1994 at 480 and NJA 1995 at 84.

26) These include Poland, Bosnia and Hercegovina and Canada, See Ferdinandusse, supra note 7, at 227.

27) According to Ferdinandusse there is 'ample evidence [...] that the international principle of legality is substantially different from the standards in many national laws, and far more minimalistic.' Ibid., at 223-4.
} 
armed forces of their enemy; depriving civilians of their liberty in contravention of international law; and seizing property protected under international law.

The indictment against Jackie Arklöv was divided in five groups of counts according to the location of the crimes: A) Grabovina, B) Gabela prison camp, C - Dretelj prison camp, D) Silos prison camp and Rotimlja, and E) various other sites. Within the five groups of counts the various acts are specified, for example counts B1 and B2 include allegations concerning violence to life and person, cruel treatment, torture, humiliating and degrading treatment, forced labour and denial of health care.

Jackie Arklöv pleaded guilty that he committed an international crime, but contested that the crime should be considered as gross and denied responsibility for parts of the indictment, for example on count B1. In the judgment the Court restated the factual background presented by the Prosecutor where she dealt with the historic background of the armed conflict in the former Yugoslav republics, the conflict between the Croatian Council of Defence (HVO) and the Bosnian Government Army (BHA), the military career of Jackie Arklöv and how he became a member of one of the $\mathrm{HVO}$ units. In connection with his service in the unit he committed atrocities against BHA prisoners of war and Bosnian Muslim civilians. Arklöv was arrested May 1, 1995 in Mostar, Bosnia and Herzegovina, and on September 8, 1995 he was sentenced to 13 years imprisonment for war crimes against prisoners of war and civilians by a Bosnian court. As part of an exchange of prisoners he was set free and he returned to Sweden August 8, 1996. The district court of Stockholm put him in detention for the aforementioned crimes August 9, 1996, which later was transformed into a travel ban. However, the travel ban was revoked in January 29, 1997 and the pre-trial proceedings (investigations) against him was discontinued on the ground that crime could not be proven. After it was made known that victims were present in Sweden the pretrial proceedings were resumed May 13, 2004.

In the judgment the Court concurred with the prosecutor's assessment on the courts competence to adjudicate in the case. Despite the fact that the acts were committed abroad, the Court considered the circumstance that Jackie Arklöv was a Swedish citizen and thus found that the requirements for Swedish jurisdiction were satisfied. In addition the court made a reference to the universality principle. In accordance with the relevant provisions regarding judgments pronounced by foreign states, the Prosecutor-General had in an explicit decision approved the request from the district prosecutor to initiate the prosecution.

The next issue was whether Jackie Arklöv could be prosecuted even though he was already convicted by a Bosnian court. The Court considered the fact that the sentence had not been enforced in its entirety and thus it held that there was no legal obstacle for prosecution. The Court continued by stating that it concurred with the prosecutor's opinion on the applicable rules of international humanitarian law. The Court described the Swedish provision on international crimes and 
declared that it was necessary to seek guidance in international humanitarian law. Thereafter, it noted that the international rules make a distinction between international and non-international armed conflicts. In the light of the fact that the armed conflict in the former Yugoslav republics have both international (the relation between Serbia and Croatia) and internal (the relation between Bosnian Serbs/Croats and Muslims) elements the Court held that 'the circumstances in the case relates to a conflict of the latter kind', i.e. an internal armed conflict. ${ }^{28}$ Considering that the primary scope of the Geneva Conventions I-IV and AP I is international armed conflicts, the Court ruled that the only treaty based provisions that were applicable were Common Article 3 of the Geneva Conventions and AP II concerning non-international armed conflicts. The Court noted that Yugoslavia had ratified the Conventions and the two Additional Protocols, which was binding also for the latter established subjects of international law. With references to the study on customary international humanitarian law of the International Committee of the Red Cross (ICRC), other studies, and UN Security Council resolutions 808 and 827 from 1993 the Court held that 'several rules in international humanitarian law, of which the primary scope is international armed conflicts, are on the basis of custom applicable in the case. ${ }^{29}$ The Court continued by stating that Article 78 in Geneva Convention IV 'should on the basis of custom be applicable in a non-international conflict of the present kind.' ${ }^{30}$ The Court noted the grave breaches regime in Article 130 of Geneva Convention III, Article 147 of Geneva Convention IV, and Article 85 of AP I, which includes murder, torture, inhuman treatment, unlawful deportation or transfer or unlawful confinement of a protected person.

After presenting its interpretation of the international humanitarian law the Court evaluated the evidence connected to each of the counts of the indictment. In that respect the Court held that most of the counts were proven and Jackie Arklöv was guilty on counts concerning violence to life and person, humiliating and degrading treatment, torture (Common Article 3 of the Geneva Conventions and AP II Article 4), unlawful confinement (Geneva Convention IV Article 78), employment of prisoners in work of humiliating and degrading character (Geneva Convention IV Article 95), inadequate care of prisoners, forced movements of civilians (AP II Articles 7 and 17), disrespecting the protection of women (AP I Article 76), and pillage (Geneva Convention IV Article 133 and AP II Article 4). The criminal offence concerned several victims at different occasions. Regardless of the aforementioned fact, the Court held that due to the wording of $\mathrm{BrB}$ Chapter 22, Section 6 the acts should be characterized as one criminal offence.

\footnotetext{
28) See Arklöv case, supra note 2, at 52. There is no official translation of the case. This and later passages from the case are translated by this author.

29) Ibid., at 54.

30) Ibid., at 55.
} 
Given the systematic nature and extent of the actual criminality the Court invoked BrB Chapter 29, Section 2, Paragraph 1(7) and considered the crime to be of gross nature. ${ }^{31}$ The Court did not agree with the statement in the indictment that Jackie Arklöv was a mercenary. In this regard the district noted that Jackie Arklöv joined the HVO because of ideological reasons (Nazi influences) and not for monetary reasons. When determining the penal value of the acts to eight years of prison the Court made references to ICTY case law, even though the court noted that the applicable rules differed. Considering that Jackie Arklöv was serving a sentence of life imprisonment for the murder of two Swedish policemen (committed May 28, 1999), the Court ordered that the previous earlier sanction should also apply to the later crime. ${ }^{32}$ The Court stated if it had determined a penalty of a fixed term imprisonment it would have considered that Jackie Arklöv was 20 years old at the time when the crimes were committed. ${ }^{33}$ In addition it would have deducted time already served in Bosnia for the acts adjudicated by the Bosnian court corresponding with the actual acts in the present case. Finally, the Court awarded reparations to the victims to be compensated by Jackie Arklöv.

\section{Comments}

The case is unique for the Swedish judicial system. There are several aspects worth commenting upon and the Court has in a thorough way explained its reasons for choosing an internationalist approach. In a Swedish context the most remarkable aspect is the fact that the Court derived guidance from international humanitarian law, which includes customary rules. Even though this approach has support in BrB Chapter 22, section 6, it gives the case a particular dimension and brings the principle of legality to the fore. Can a domestic provision with references to custom bring about criminal responsibility?

The Court has made references to the ICRC and resolutions from the UN Security Council when it held that certain rules in international humanitarian

\footnotetext{
31) BrB Chapter 29, Section 2, Paragraph 1(7): 'In assessing penal value, the following aggravating circumstances shall be given special consideration in addition to what is applicable to each and every type of crime: [...] whether a motive for the crime was to aggrieve a person, ethnic group or some other similar group of people by reason of race, colour, national or ethnic origin, religious belief, sexual orientation or other similar circumstance.'

32) BrB Chapter 34, Section 1, Paragraph 1(1): 'If a person who has been sentenced for a crime to imprisonment, conditional sentence, probation or closed juvenile care is found to have committed another crime prior to the sentence, or commits a new crime subsequent to the sentence but before the sanction has been fully implemented or has been otherwise terminated, the court may, with due regard to what is provided in Sections 2-7 concerning certain cases, and the particular circumstances: 1 . order that the earlier sanction imposed shall also apply to the second crime, ....'

33) BrB Chapter 30, Section 5, Paragraph 2: 'If a person who has attained the age of eighteen but not twentyone has committed a crime, the court may impose imprisonment only if, in view of the penal value of the crime or other special reasons, this course of action is justified.'
} 
law, of which the primary scope is international armed conflicts, are on the basis of custom applicable in the case. The Court refrained from a making a reference to the groundbreaking decision in Tadić where the ICTY Appeals Chamber was confronted with the same question. ${ }^{34}$ A plausible explanation for this omission may be the fact that judicial decisions in them selves do not create binding customary rules; they are rather 'subsidiary means for the determination of rules of law. 35

Already during the first round of cancelled investigations concerning Jackie Arklöv, Iain Cameron put attention on the issue of legal uncertainty, both in regard to the nature of conflict in former Yugoslavia and whether the "grave breaches" regime of the Geneva Conventions applies in internal conflicts and the vagueness of the definition of the crime in BrB Chapter 22, Section 6. He mentions that

'[i]n some countries where prosecutions have been brought against people suspected of war crimes in former Yugoslavia there has been a problem regarding the nature of the conflict ${ }^{36}$ and states that BrB Chapter 22, Section 6 'is unique for Swedish law, defined, at least in part, by reference to international law and thus constitutes a form of "sector monism" in the otherwise dualistic Swedish system. As such, some prosecutors may consider that the offence entails an unacceptable large degree of legal uncertainty. ${ }^{37}$

Considering the survey made by Ward N. Ferdinandusse, the direct application of Criminal law in national courts has resulted in different outcomes. The French Court of Cassation has held as regards to the Geneva Conventions that 'their provisions have too general a character to be able directly to create rules on extraterritorial jurisdiction in criminal matters. ${ }^{38}$ In contrast, an English Court of Appeal has found that the prosecution of international crimes does not require a statute but instead that 'a rule of international law is capable of being incorporated into domestic law so as to found an indictment which, if proved, can result in punishment. ${ }^{39}$

34) Prosecutor v. Dusko Tadić, Decision on the Defence Motion for Interlocutory Appeal on Jurisdiction, ICTY Appeal Chamber, 2 October 1995, paras. 79-94.

35) Statute of the International Court of Justice, San Francisco 26 June 1945, 1 UNTS XVI, Article $38(1)(d)$.

36) See Cameron, supra note 6, at 143.

37) Ibid., at 148.

38) France, Court of Cassation, In re Javor, 26 March 1996, Bull. Crim. No. 132 quoted from Ferdinandusse, supra note 7, at 65. See also the judgment of 6 November 1995 in Reporters sans frontières v. Mille Collines (at 48-51), where the Paris Court of Appeal came to a similar conclusion, see Cassese, supra note 4, at 304 and Ferdinandusse, supra note 7, at 65, note 406.

39) U.K., Court of Appeal, Jones \& Milling, Olditch \& Pritchard, Richards v. Gloucestershire Crown Prosecution Service, 21 July 2004, [2004] EWCA Crim 1981, para. 30; see Ferdinandusse, supra note 7 , at 59 . 
One of the issues is why the Court imposed criminal liability with reference to customary international rules. Would it not have sufficed with the treaty provisions in Common Article 3 of Geneva Conventions and AP II? At a first glance it appears as the alleged acts are covered by the treaty provisions applicable in internal armed conflicts, which makes it unnecessary to rely upon customary international law. Nevertheless, there were good reasons for the Court to raise the issue. Firstly, by the wording of BrB Chapter 22, Section 6 it is apparent that recognized principles and rules relating to international humanitarian law are applicable. However, among legal scholars in Sweden (Nils Jareborg and Iain Cameron) there appears to be different opinions whether criminal responsibility can be based on customary international law. Secondly, the Prosecutor has in her indictment stated that Jackie Arklöv had violated principles and rules relating to international humanitarian law. Thirdly, under a closer scrutiny of the case one may observe that some of the alleged acts may only become criminalized if certain rules in international humanitarian law, of which the primary scope is international armed conflicts, are considered to applicable on the basis of custom. This is obvious in relation to unlawful confinement which is prohibited according to Article 78 of Geneva Convention IV, but not according to the treaty provisions in humanitarian law that regulates internal armed conflicts. A considerable amount of the acts concerned unlawful confinement of protected persons, which made the issue of applicable rules relevant for the question whether the crime was of the normal degree or gross. Considering statutes of limitation, ${ }^{40}$ the characterization of the crime would in its turn have an effect on reparations to victims and a future conversion of the abovementioned life sentence from May 28, 1999. Thus, it was necessary for the Court to examine whether the reference in $\mathrm{BrB}$ Chapter 22, Section 6 to customary international law could be the basis for imposing criminal liability. The conclusion reached by the Court was affirmative and it made a reference to the ICRC study on customary international law. ${ }^{41}$

One of the rules that the experts of the ICRC study found to be applicable in both international and non-international armed conflicts is that '[a]rbitrary deprivation of liberty is prohibited' (Rule 99).

Even though there is no double criminality rule in BrB Chapter 2, Section 3, Paragraph 6 it may be of interest for the question of the content of customary international law to examine national rules on unlawful confinement, particularly

40) Following the rules on limitations on sanctions BrB Chapter 35, Section 1 a sanction for an international crime of the normal degree may not be imposed after ten years and for a gross international crime the limit is twenty-five years. There are no special rules for international crimes and there is no customary rule in international law providing for the opposite, see Cassese, supra note 4, at 319. The alleged acts took place in July 1993 and the present proceedings were initiated May 13, 2004.

41) Jean-Marie Henckaerts and Louise Doswald-Beck (Eds.), Customary international humanitarian law, Cambridge 2005. 
in Sweden and the republics of former Yugoslavia. The ICRC study found that ' $[w]$ hile all state have legislation specifying the grounds on which a person may be detained, more than 70 of them were found to criminalise unlawful deprivation of liberty during armed conflict.' Illegal arrests and detention are war crimes in Bosnia and Herzegovina (Article 154(1) of the Criminal Code (1998)) and in Republika Srpska (Article 433(1) of the Criminal Code (2000)). Unlawful confinement of civilians is war crime in Croatia (Article 158(1) of the Criminal Code (1997)). As previously stated depriving civilians of their liberty is contravention of international law is criminalized in Sweden (BrB Chapter 22, Section 6). The study did not find any official contrary practice. ${ }^{42}$ Thus, there is good support for the conclusion that unlawful confinement is a crime in international and noninternational armed conflicts according to customary international law. In the context of the present case it is notable that Gerhard Werle holds the opposite view: '[i]n non-international armed conflict, unlawful confinement is not a war crime under either the Rome Statute or customary international law. ${ }^{33}$

Has the Court adopted a more lenient standard for the application of the international principle of legality? Can custom constitute law in the sense of nullum crimen sine lege? Are offences such as illegal confinement sufficiently developed to form the basis for criminal liability? Considering the wording of BrB Chapter 22, Section 6, the explicit and accessible rules in humanitarian law and several national jurisdictions, it is the present author's view that there has not existed any legal uncertainty whether it is a crime to illegally confine protected persons. The argument and account for State practice made in the ICRC study on customary international law is convincing. Therefore, it is submitted that the Court's conclusion that certain rules in international humanitarian law, of which the primary scope is international armed conflicts, are applicable in the case on the basis of custom is correct. It has also made a correct interpretation of the content of customary international law. Nevertheless, Iain Cameron observation that $\mathrm{BrB}$ Chapter 22, Section 6 is 'a form of "sector monism" in the otherwise dualistic Swedish system' is valid, which may cause future problems in similar cases. Even though the present author argues that the district court made a correct finding in the Arklöv case, it is unfortunate for the sake of legal certainty that the judgment stayed at the first instance. The possibility that an other district court, an appeal court or the Supreme Court, in possible future case, will adopt a less internationalist approach can not be ruled out. One solution to this dilemma would be that the Swedish Government makes use of the report presented by Swedish Commission on International Criminal Law and presents a legislative proposal.

42) Ibid., volume 1 at 347-52 and volume 2, part 2 at 2328-37.

43) Gerhard Werle, Principles of International Criminal Law, $\bullet \cdot \mathrm{M} \bullet \mathrm{C}$ Asser Press, The Hague, 2005 , at 323, para. 950 . 
The fact that the proposal from Swedish Commission on International Criminal Law provides an exhaustive list of prohibited acts may have the consequence that the future Act on International Crimes will have a different scope than the present provision $\mathrm{BrB}$ Chapter 22, Section 6, with the risk of under-inclusion in comparison with customary international law. For example, according to the proposal on a new Act on International Crimes unlawful confinement is only a war crime in international armed conflicts and during occupation (Chapter 4, Section 3, Paragraph 3(4)). However, the proposal also includes a provision introducing in Swedish law unlawful confinement as a crime against humanity which may occur in the absence of an armed conflict, but it requires that additional elements concerning the widespread or systematic nature of the attack is fulfilled (Chapter 3, Section 2, Paragraph 2(4)). Thus, if the proposal of Swedish Commission on International Criminal Law had been the applicable law in the Arklöv case, it would still have been possible to convict him, but it would have required an adjustment of the indictment. In light of the present case there are good reasons for Sweden not only to adopt a new Act on International Crimes, but also to make sure that the scope of the Act meets international standards. 